\title{
Screening of antibiofilm and anti-quorum sensing activty of Actinomycetes isolates extracts against aquaculture pathogenic bacteria
}

Gloria Raissa ${ }^{1}$, Diana Elizabeth Waturangi ${ }^{1 *}$ and Dinamella Wahjuningrum ${ }^{2}$

\begin{abstract}
Background: Indonesia is the third largest producer of fish and other aquaculture products in the world, making this industry a major contributor in the economy of Indonesia. However, this industry continually overcome challenges, one of them are bacterial outbreaks. In addition, the emergence of these bacterial outbreaks were worsen due to the biofilm produced by many significant pathogenic bacteria and the impact of increased antibiotic resistance. These issues have become a global concern, because antibiotics are currently one of the main treatments available to overcome this problems. Therefore, studies aimed at finding and characterizing bioactive compounds to combat these issues. In this study actinomycetes isolates were screened and characterized for their bioactive compounds produced which have inhibitory and destructive activity and also QS inhibitors against biofilm structure of aquatic pathogenic bacteria, such as Vibrio harveyi, A. hydrophila, and S. agalactiae.

Result: Extracts $(20 \mathrm{mg} / \mathrm{mL})$ produced by sixteen Actinomycetes isolates showed anti-quorum sensing activity towards reporter stain Chromobacterium violaceum wild-type. Most of these extracts showed better inhibitory activity on all of the pathogenic bacteria biofilm structure tested than the destructive activity on the preformed of those biofilm structure. Subsequently, we also performed characterization of bioactive compound and found that in this study, polysaccharide is the most common antibiofilm agents, which were responsible to their antibiofilm activity. Finally, we found that the value of $\mathrm{LC}_{50}$ of all extracts tested were more than $1 \mathrm{mg} / \mathrm{mL}$, thereby all of extracts tested did not show cyto-toxic effect against Artemia salina.
\end{abstract}

Conclusion: All of the extracts of Actinomycetes isolates showed promising inhibitory activity towards biofilm structure of pathogenic bacteria tested. So far, all of the extracts are potential to be QS inhibitors and antibiofilm agents of all pathogenic bacteria tested.

Keywords: Actinomyces, Antibiofilm, Aquatic pathogen, Biofilm, Quorum sensing

\footnotetext{
* Correspondence: diana.waturangi@atmajaya.ac.id

'Master of Biotechnology Program, Faculty of Biotechnology, Atma Jaya

Catholic University of Indonesia, Jalan Jenderal Sudirman, Jakarta 12930, Indonesia

Full list of author information is available at the end of the article
}

(c) The Author(s). 2020 Open Access This article is licensed under a Creative Commons Attribution 4.0 International License, which permits use, sharing, adaptation, distribution and reproduction in any medium or format, as long as you give appropriate credit to the original author(s) and the source, provide a link to the Creative Commons licence, and indicate if changes were made. The images or other third party material in this article are included in the article's Creative Commons licence, unless indicated otherwise in a credit line to the material. If material is not included in the article's Creative Commons licence and your intended use is not permitted by statutory regulation or exceeds the permitted use, you will need to obtain permission directly from the copyright holder. To view a copy of this licence, visit http://creativecommons.org/licenses/by/4.0/ The Creative Commons Public Domain Dedication waiver (http://creativecommons.org/publicdomain/zero/1.0/) applies to the data made available in this article, unless otherwise stated in a credit line to the data. 


\section{Background}

The aquaculture industry is one of the main producers in the food sector globally by providing high-protein food source for world population. In fact, capita food fish consumption increased by $1.5 \%$ per year from $9.0 \mathrm{~kg}$ in 1961 to $20.5 \mathrm{~kg}$ in 2018. Indonesia is the third largest producer of fish aquaculture products in the world, which it has been estimated that Indonesia had produced 5.4 million tons of fishes, 3.5 million tons of aquaculture products including aquatic plants, and 0.9 million tons of finfish until 2018. In addition to that, it is known that Indonesia is the second largest producer of crustaceans producing 0.9 million tons of them [1]. However this industry is continually overcoming the same challenges, one of them are bacterial outbreaks, causing crop failures in the aquaculture industry and income loss. This emergence of these bacteria outbreaks also cause problems especially due to the biofilm produced by several pathogenic bacteria and its impact of increased antibiotic resistance [2].

Biofilms are bacterial multispecies communities, which attach to a surface and are embed by extracellular polymeric substances (EPS). These communities are formed as a bacterial response in the face of hostile environments, such as nutritional deficiencies, desiccation, and high frequency antibiotic and disinfectant exposure. The formation of biofilm structure is known to have implications for the increase in bacterial resistance to immune system of the host and antimicrobial agents, one of which is antibiotics, up to 1000 times the normal dose [3]. This is due to the nature of the sessile cells (cells which live within the biofilm structure) and biofilm structure. For example, the low nutrient state in the biofilm structure could result in cell dormancy, where the rate of cell metabolic is very low, causing cells to become insensitive to particular type of antibiotics, such as $\beta$-lactam [4]. In addition, close cell contact within biofilm structure is known to increase the efficiency of horizontal gene transfer, resulting in increased the spread of genes associated with resistance [5].

In the aquaculture system, biofilm structures were also found. It is known that there are many fish pathogenic bacteria which also have the ability to form these structures, such as Vibrio harveyi and Aeromonas hydrophila. It has become a concern, because biofilm structures can act as reservoirs of those bacteria populations and this structure makes the bacteria become more resistant to antibiotics [6]. This also has become major concern, considering antibiotics are major front liner treatment in the face bacterial outbreak. In addition, the prolonged use of antibiotics in aquaculture could increase the spread of resistance genes even to humans. Due to the nature of antibiotics being relatively stable and non-biodegradable, thereby the residual of these compounds could remain in the aquaculture product for human consumption [7].
The process of biofilm formation is regulated by a cell to cell communication, called quorum sensing (QS) system. This system is also involved in various regulations of many gene expressions, such as bioluminescence, secretion of virulence factors, and formation of biofilm structures [8], making this system a promising target in dealing with infections and bacteria pathogenicity. Therefore, studies aimed at finding and characterizing bioactive compounds with antibiofilm activity is necessary, as an alternative step in overcoming this problem.

Natural products have become the source of novel therapeutics discovery, hence microbes as one of them have also become the primary source of drug discovery [9]. Actinomycetes are Gram-positive bacteria which are found in nature. These bacteria are known to produce many bioactive compounds [10]. Based on our previous studies, we found extracts of actinomycetes isolates which showed both inhibitory and destructive antibiofilm towards biofilm structure of Gram-positive and Gram-negative associated bacteria, such as Pseudomonas aeruginosa, Salmonella typhimurium, Vibrio cholera, Bacillus cereus, and Staphylococcus aureus. In addition, these extracts also produced quorum quenching compounds [11]. Therefore, in this study we screen the antibiofilm and anti-quorum sensing activity of these extracts on several aquaculture pathogenic bacteria.

\section{Result}

\section{Bacterial cultivation}

Sixteen isolates of Actinomycetes recovered from marine environments from our previous study were cultivated in yeast malt extract agar (YMEA) $+1 \%$ calcium carbonate. All of these isolates were attached on agar media and their colonies showed calcification due to the addition of calcium carbonate.

\section{Screening of anti-quorum sensing activity}

All of the isolates showed anti-quorum sensing activity against indicator bacteria, namely Chromobacterium violaceum wild-type. It is characterized by the translucent zone around the straight streak area of the isolate (Fig. 1) (Table 1). Therefore, these isolate were used in the further assay.

\section{Detection of anti-quorum sensing activity}

In this assay, all of the isolates which showed antiquorum sensing activity in the previous assay were further tested. Extracts of Actinomycetes isolates $(20 \mathrm{mg} /$ $\mathrm{mL}$ ) were spotted into each well. Table 1 showed that the result was varied. Based on the translucent zone around the well, the inhibitory activity was categorized into three: $(+) ;(+)(+) ;(+)(+)(+)$ indicating weak; moderate; and strong inhibition, respectively (Fig. 2$)$. 

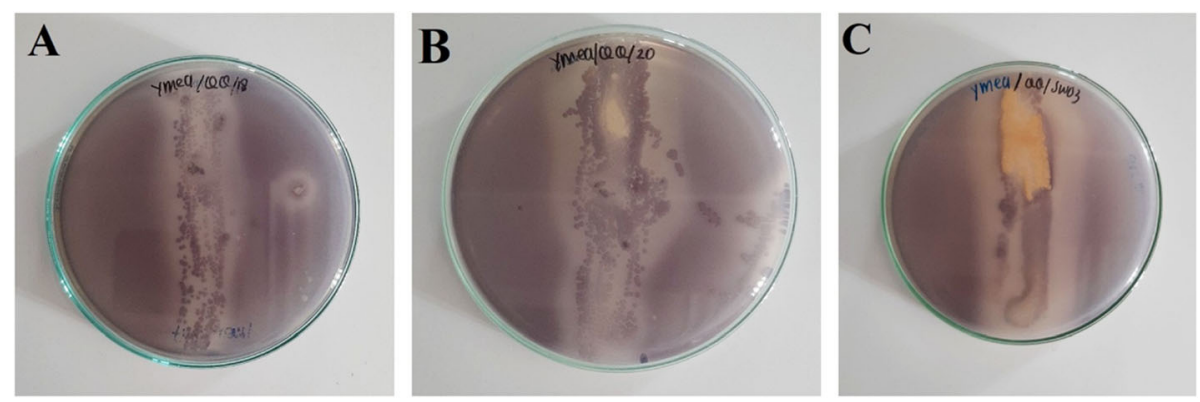

Fig. 1 Result of screening of anti-quorum sensing activity of several Actinomycetes isolates (a: 18 PM; b: 20 PM; c: SW03)

\section{Antibacterial activity assay}

Antibacterial assay was necessary to be performed to avoid false-positive results in antibiofilm activity assay (Fig. 3). In this assay, extracts of Actinomycetes isolates $(20 \mathrm{mg} / \mathrm{mL})$ were spotted into each well. Based on the result there were several isolates, which showed antibacterial activity, such as SW17 and 15, 14, CW01, 16, 18 , and 20 against $V$. harveyi and $S$. agalactiae, respectively (Fig. 2) (Table 1). These isolates were ruled out in further assay.

\section{Antibiofilm activity assay}

Antibiofilm activity assay was carried out to quantify the inhibitory and destructive activity of the isolates against

Table 1 Result of detection of anti-quorum sensing activity and anti-bacterial activity assay of Actinomycetes isolates extracts $(20 \mathrm{mg} / \mathrm{mL})$

\begin{tabular}{|c|c|c|c|c|}
\hline \multirow[t]{2}{*}{ Isolates } & \multirow{2}{*}{$\begin{array}{l}\text { Detection } \\
\text { of QS } \\
\text { inhibitors }\end{array}$} & \multicolumn{3}{|c|}{ Antibacterial activity assay } \\
\hline & & $\overline{\mathrm{AH}}$ & VH & SAG \\
\hline TB12 & +++ & - & - & - \\
\hline KP110 & ++ & - & - & - \\
\hline $1 \mathrm{AC}$ & +++ & - & - & - \\
\hline SW03 & +++ & - & - & - \\
\hline CW17 & + & - & - & - \\
\hline $16 \mathrm{PM}$ & ++ & - & - & $+(\mathrm{D}=2.2 \mathrm{~cm})$ \\
\hline $12 \mathrm{AC}$ & +++ & $+(\mathrm{D}=2 \mathrm{~cm})$ & - & - \\
\hline $20 \mathrm{PM}$ & +++ & - & - & $+(\mathrm{D}=1.5 \mathrm{~cm})$ \\
\hline $18 \mathrm{PM}$ & ++ & - & - & $+(\mathrm{D}=1.2 \mathrm{~cm})$ \\
\hline 14 PM & +++ & - & - & $+(\mathrm{D}=2.1 \mathrm{~cm})$ \\
\hline CW01 & + & - & - & $+(\mathrm{D}=2.5 \mathrm{~cm})$ \\
\hline SW17 & + & - & $+(D=2 \mathrm{~cm})$ & - \\
\hline SW16 & ++ & - & - & - \\
\hline SW14 & +++ & - & - & - \\
\hline 15 PM & +++ & - & - & $+(\mathrm{D}=1.1 \mathrm{~cm})$ \\
\hline $11 \mathrm{AC}$ & + & - & - & - \\
\hline
\end{tabular}

pathogenic bacteria tested. Based on the result of the assay, most of the isolates showed higher inhibitory activity compared to their destructive activity. Table 2 showed that 16 PM, CW01, and CW17 showed highest inhibitory activity against each pathogenic bacteria tested: 85.11, 44.23, and 53.42\% against $A$. hydrophila, $V$. harveyi, $S$. agalactiae respectively. While, CW17 and SW14 showed highest destructive activity against pathogenic bacteria tested: 74.47 and $51.88 \%$ against $A$. hydrophila and $V$. har$v e y i$, respectively. In addition, based on this assay, all of the isolates work most effectively against specific pathogenic bacteria in specific mechanism of action (Fig. 3).

\section{Determination of the bioactive compound}

The determination of these compounds was performed by static inhibition assay using the crude extract of each Actinomycetes isolates. The pre-treatment using proteinase-K, nuclease, and $\mathrm{NaIO}_{4}$ could decrease the antibiofilm activity due to the destruction of active compounds, which is responsible to its antibiofilm activity. In this study, we found that polysaccharides are the most commonly found compounds which were responsible to their antibiofilm in extracts tested. Figure 4c showed that the pre-treatment of extract $20 \mathrm{PM}$ using $\mathrm{NaIO}_{4}$ decrease its inhibitory activity towards biofilm structure of $A$. hydrophila. While pretreatment using proteinase- $\mathrm{K}$ and nuclease showed relatively no effect to its antibiofilm activity (Fig. 4a and b). Similarly, Fig. $5 \mathrm{c}$ and $\mathrm{f}$ showed that pre-treatment of extracts $11 \mathrm{AC}$ and CW17 using $\mathrm{NaIO}_{4}$ decrease their inhibitory activity towards biofilm structure of $S$. agalactiae. While pre-treatment using proteinase- $K$ and nuclease showed no effect to its antibiofilm activity (Fig. $4 \mathrm{a}$ and b).

In addition, Fig. $4 \mathrm{~d}$ showed that pre-treatment using proteinase-K decrease inhibitory activity of extract TB12 towards biofilm structure of $A$. hydrophila. While, pretreatment of nuclease and $\mathrm{NaIO}_{4}$ showed no effect to those activity (Fig. 4e and f), indicating that the compound which was responsible to this activity is protein. Other than that, we also found that nucleic acid might be another compound which was responsible to inhibitory activity of these extracts tested as seen in Fig. 6b, which 

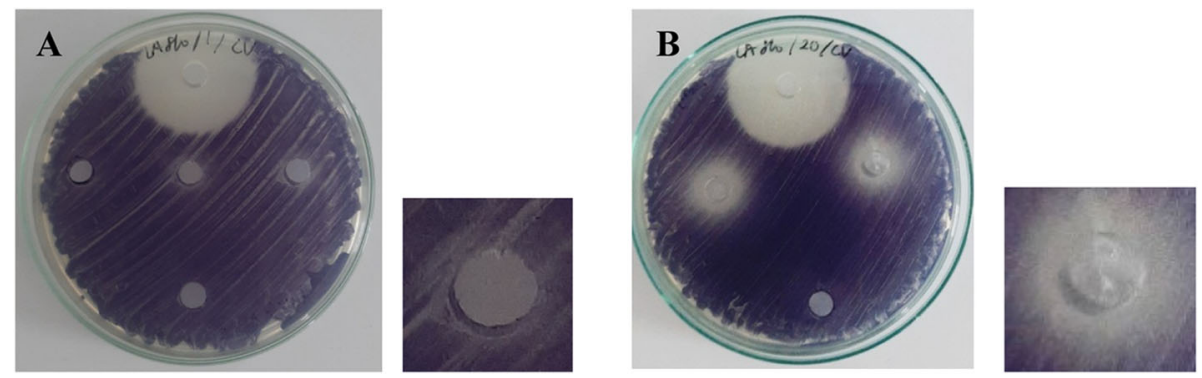

Fig. 2 Result of detection of anti-quorum sensing activity of a) Isolate 1 AC b) Isolate 20 PM against C. violaceum wild-type. ${ }^{*}$ The top well is a positive-control; well in the middle of the plate containing the extract of Actinomycetes isolates; and the lowest well is a negative-control

showed that pre-treatment of CW01 using nuclease decrease those activity. While, pre-treatment using proteinase- $\mathrm{K}$ and $\mathrm{NaIO}_{4}$ showed no effect (Fig. 6a and c).

\section{Brine shrimp lethality assay}

Seven potential Actinomycetes isolates extracts which showed the highest antibiofilm activity was tested using BSLA method. This assay was performed in five replicates and two different batches. Table 3 showed the $\mathrm{LC}_{50}$ value of these isolates, which were more than $1 \mathrm{mg} / \mathrm{mL}$.

\section{Discussion}

Quorum sensing is an inter-cell communication system, which aims to regulate gene expressions from cell

Table 2 Antibiofilm activity of extracts of Actinomycetes isolates $(20 \mathrm{mg} / \mathrm{mL})$ against aquatic pathogenic bacteria

\begin{tabular}{|c|c|c|c|c|c|c|}
\hline \multirow[t]{2}{*}{ Isolates } & \multicolumn{3}{|c|}{ Inhibition (\%) } & \multicolumn{3}{|c|}{ Destruction (\%) } \\
\hline & VH & $\mathrm{AH}$ & SAG & $\mathrm{VH}$ & $\mathrm{AH}$ & SAG \\
\hline $\mathrm{TB} 12$ & 28.77 & 78.67 & 26.34 & 36 & 22.62 & 18.09 \\
\hline KP110 & 26.37 & 34.49 & 27.90 & 0 & 15.22 & 42 \\
\hline $1 \mathrm{AC}$ & 0 & 33.33 & 3.30 & 26.65 & 29.13 & 33.47 \\
\hline SW03 & 0 & 75.57 & 0 & 0 & 38.83 & 14.79 \\
\hline CW17 & 0 & 74.47 & 53.42 & 0 & 16.57 & 18.16 \\
\hline $16 \mathrm{PM}$ & 36.66 & 85.11 & - & 0 & 17.31 & - \\
\hline $12 \mathrm{AC}$ & 33.07 & - & 23.86 & 0 & - & 36.78 \\
\hline $20 \mathrm{PM}$ & 0 & 82.44 & - & 0 & 28.46 & - \\
\hline $18 \mathrm{PM}$ & 0 & 76.90 & - & 0 & 76.54 & - \\
\hline $14 \mathrm{PM}$ & 32.94 & 78.60 & - & 0 & 14.54 & - \\
\hline CW01 & 44.23 & 76.10 & - & 23.52 & 59.75 & - \\
\hline SW17 & - & 37.99 & 27.23 & - & 25.02 & 27.99 \\
\hline SW16 & 24.08 & 27.45 & 0 & 0 & 3.83 & 0 \\
\hline SW14 & 35.29 & 12.62 & 0 & 51.88 & 21.35 & 0 \\
\hline $15 \mathrm{PM}$ & 0 & 9.85 & - & 0 & 0 & - \\
\hline $11 \mathrm{AC}$ & 35.99 & 79.17 & 71.52 & 39.87 & 23.54 & 36.33 \\
\hline
\end{tabular}

VH V. harveyi, AH A. hydrophila, SAG S. agalacatiae ATCC 27956 communities by producing, detecting, and responding to self-synthesized small signal molecules, called autoinducers [12]. Many previous studies reported the involvement of this system in the bacterial virulences, some of them are the formation, maintenance, and dispersal of biofilm structures. Therefore, one approach that is considered promising is to target this system with the aim of either inhibiting or destructing biofilm structures [13]. Based on the result of screening of anti-quorum sensing activity, we found sixteen Actinomycetes isolates which showed anti-quorum sensing activity. This is confirmed by the result of the detection of anti-quorum sensing activity, that the extract of these isolates showed inhibitory activity against violacein pigment production of reporter strain C. violaceum wildtype without affecting their growth. Given this information, these isolates were further tested against aquatic pathogenic to confirm whether their anti-quorum sensing activity could suppress the pathogenic bacteria tested.

In this study, we also found that several Actinomycetes isolates showed anti-bacterial activity, such as SW17 and CW01 against $V$. harveyi and S. agalactiae, respectively. In this case, these isolates were not used in further assay, due to the false-positive result which potentially could happen. In addition, antibiofilm non-biocidal strategies target bacterial behavior rather than bacterial fitness. Therefore, they are less likely causing resistance in bacteria [14].

The antibiofilm assay showed varied results. Most of the isolates showed promising antibiofilm activity against specific pathogenic bacteria in specific mechanism of action. For example, isolate $16 \mathrm{PM}$ showed $85.11 \%$ inhibitory activity against $A$. hydrophila. Given the information from previous assay, that these isolates showed anti-quorum sensing activity then it is possible that these isolates might produce quorum sensing inhibitors (QSI) which interfere the quorum sensing system of pathogenic bacteria tested which resulting in inhibition and destruction of their biofilm structure. QSI might work in three manners, namely 1) inhibiting the production of signaling molecules; 2) directly degrading signal molecules; and 3) inhibiting the binding of signaling molecules to the receptors. In addition, QSIs are considered as specific 

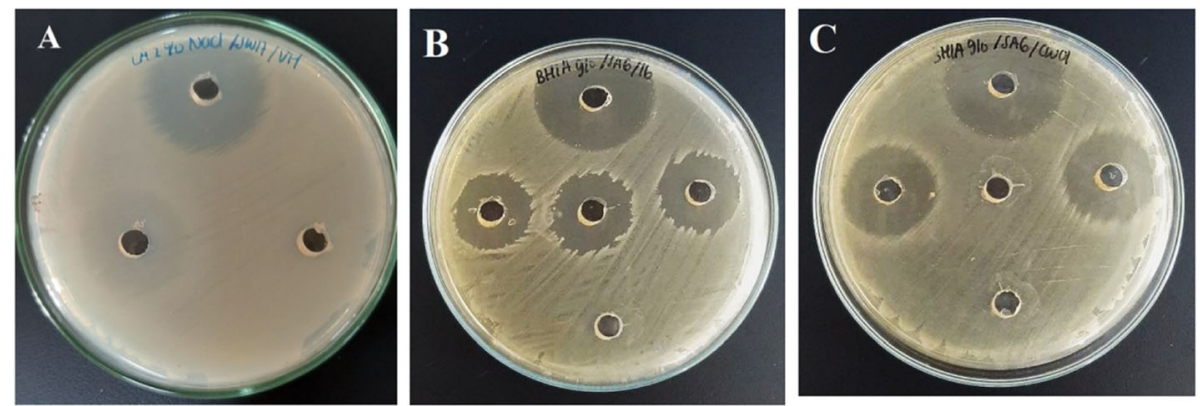

Fig. 3 Result of antibacterial assay a) Isolate SW17 against Vibrio harveyi b) Isolate 16 PM against Streptococcus agalactiae c) Isolate CW01 against Streptococcus agalactiae. *The top well is a positive-control; well in the middle of the plate containing the extract of Aktinomycetes isolates; and the lowest well is a negative-control

antibiofilm molecules since each bacteria have different QS systems [13].

The nature of QSIs could be enzymatic or nonenzymatic. In the case of enzymatic, signal molecules might be enzymatically degraded by Acylhomoserine lactone (AHL) lactonase and AHL acylase, hence prevent their accumulation and subsequent activation of their QS systems. Several reports have reported that some bacteria, such as Bacillus, Klebsiella pneumonia, Pseudomonas aeruginosa, and Streptomyces sp. M664 showed ability to degrade AHL signal molecules of other bacteria by secreting enzymes, such as lactonase and acylases. These enzymes are known to be able to hydrolyze homoserine lactone (HSL) ring and amide bonds of AHL molecules, respectively [15]. In addition, based on the study conducted by [16], they found that Shewanella sp. MIB015 showed obvious degrading activity against AHL-mediated production of exoprotease in Aeromonas sp. Similarly, other study also reported that by mutating ahyI, a gene coding for AHL signal synthesis enzymes, resulted in the formation of unstructured biofilm in Aeromonas hydrophila [17]. All of these data suggest that by interfering the quorum system of these pathogenic

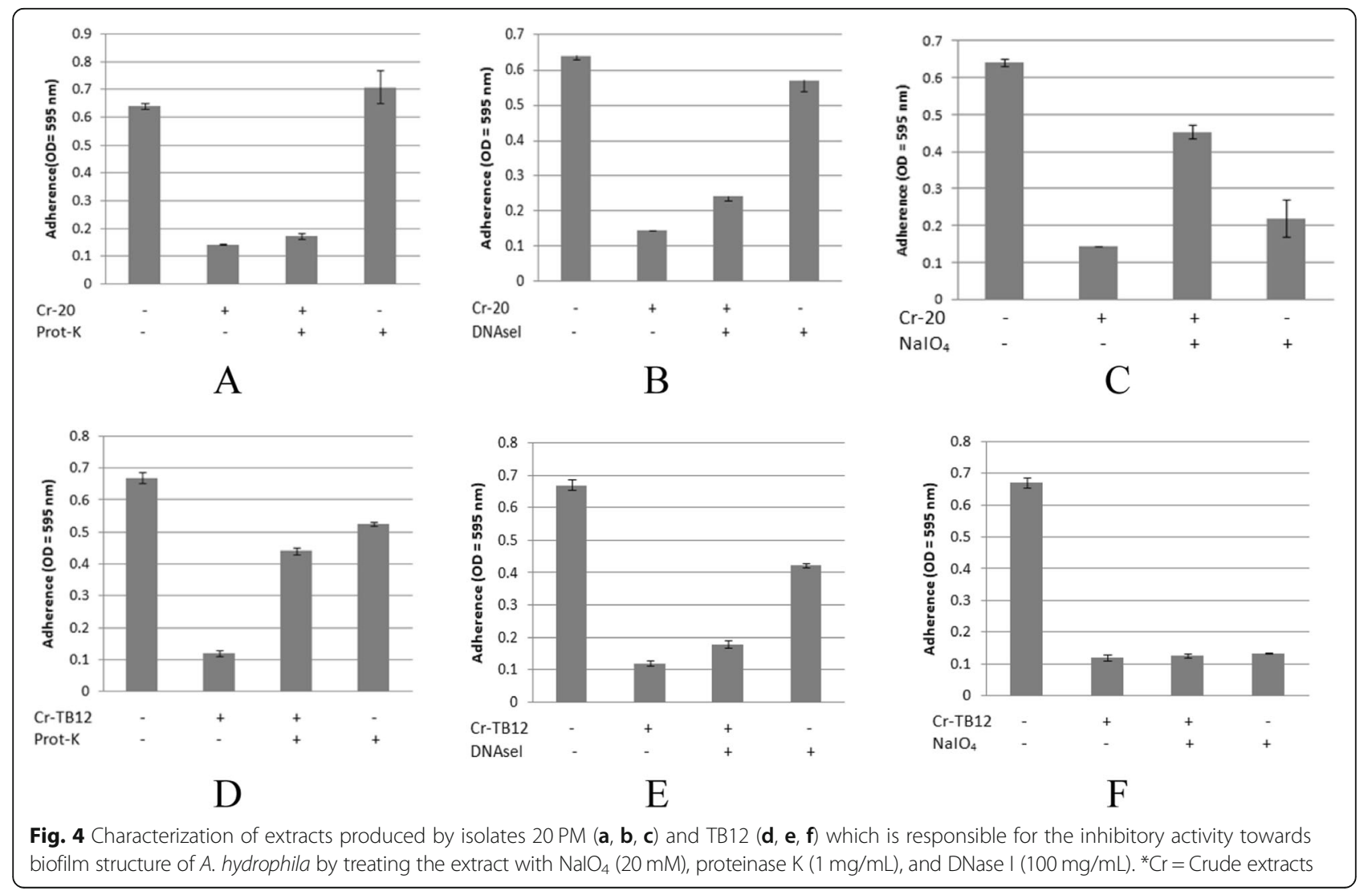




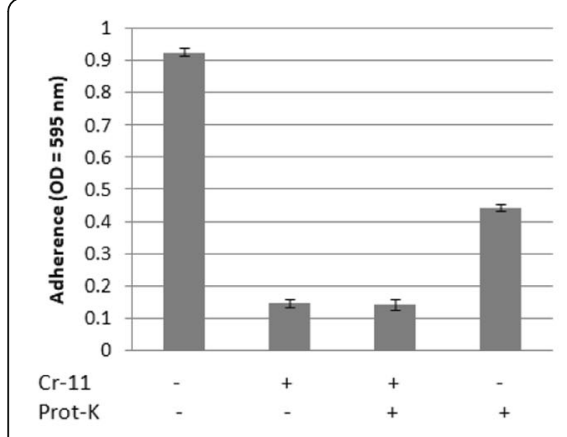

A

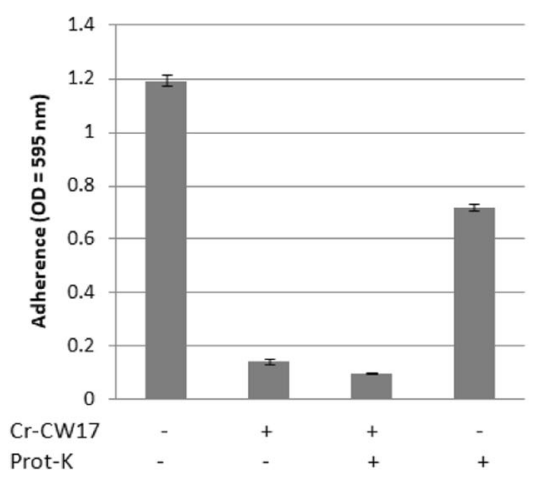

D

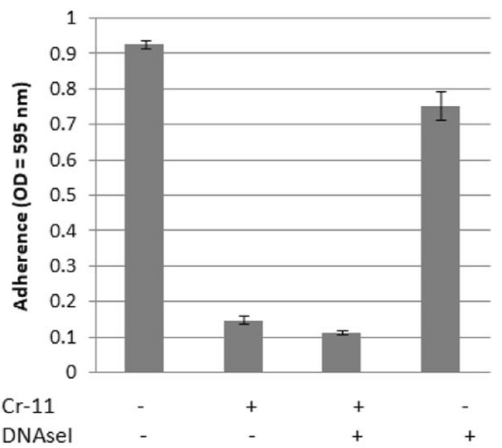

B

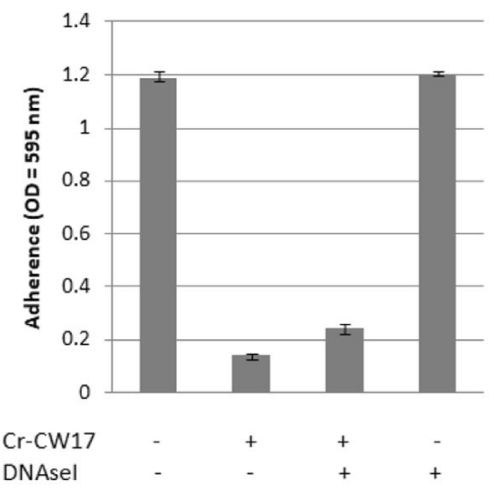

E

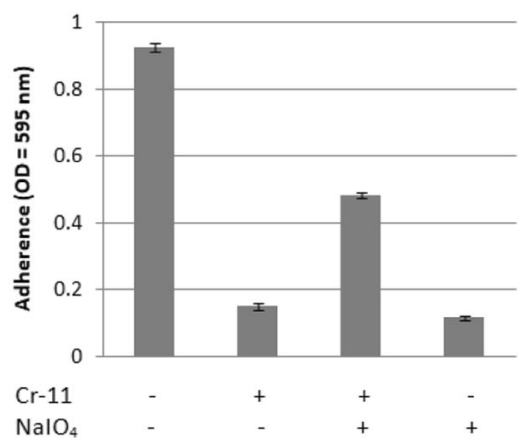

C

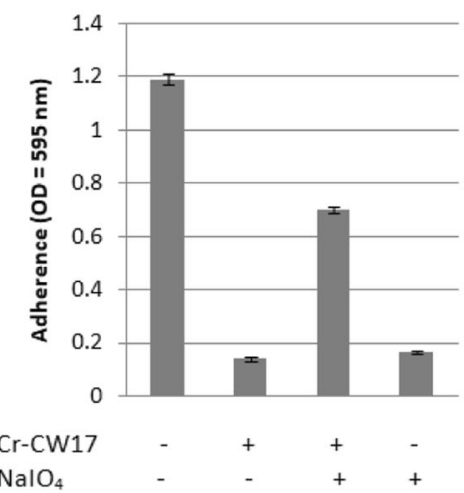

F

Fig. 5 Characterization of extracts produced by isolates $11 \mathrm{AC}(\mathbf{a}, \mathbf{b}, \mathbf{c})$ and TB12 (d, e, $\mathbf{f})$ which is responsible for the inhibitory activity towards biofilm structure of $\mathrm{S}$. agalactiae by treating the extract with $\mathrm{NalO}_{4}(20 \mathrm{mM})$, proteinase $\mathrm{K}(1 \mathrm{mg} / \mathrm{mL})$, and DNase I (100 mg/mL)

bacteria, it might lead to interference of their virulence one of them is formation of biofilm structure.

In this study, we also performed characterization of bioactive compound by treating several selected extracts with protease, DNAseI, and $\mathrm{NaIO}_{4}$. Protease and nuclease break down protein and nucleic acid, respectively. While, $\mathrm{NaIO}_{4}$ is known to be able to hydrolyze polysaccharides by oxidizing the carbons bearing vicinal hydroxyl groups and cleaving the $\mathrm{C}-\mathrm{C}$ bonds [18]. In this case, we expected that treatment of these extracts were going to digest the responsible compound thereby caused a decrease of antibiofilm activity. The result of this assay was varied. In this case, several extracts such as $20 \mathrm{PM}, 11 \mathrm{AC}$, and CW17 showed a decrease of antibiofilm activity after being treated with

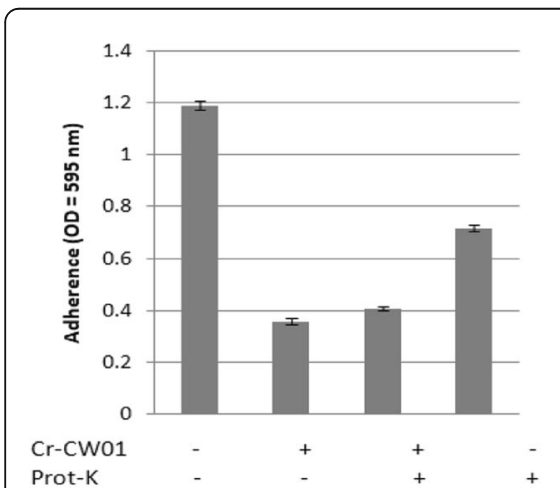

A

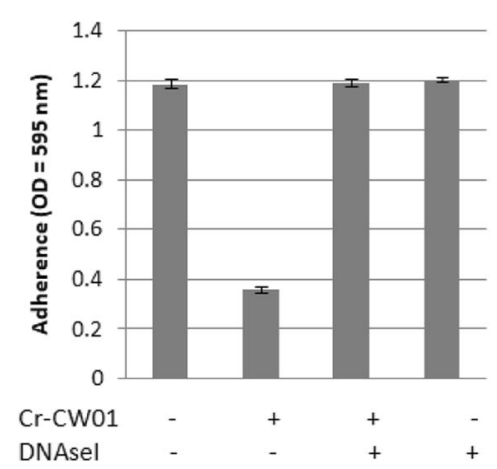

B

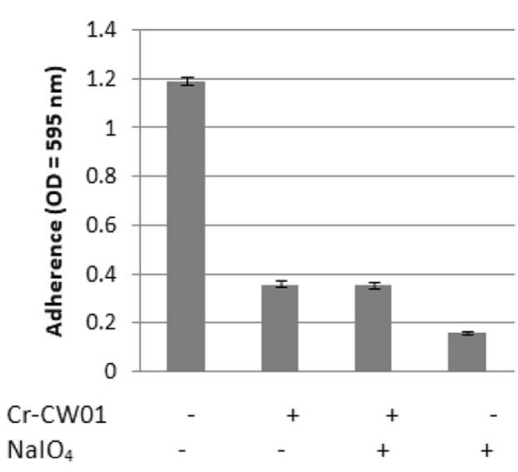

C

Fig. 6 Characterization of extracts produced by isolates CW01 (a, b, c) which is responsible for the inhibitory activity towards biofilm structure of S. agalactiae by treating the extract with $\mathrm{NalO}_{4}(20 \mathrm{mM})$, proteinase $\mathrm{K}(1 \mathrm{mg} / \mathrm{mL})$, and DNase I $(100 \mathrm{mg} / \mathrm{mL})$ 
Table 3 The result of BSLA of several Actinomycetes isolates

\begin{tabular}{ll}
\hline Isolates & LC $_{\mathbf{5 0}}(\mathbf{m g} \boldsymbol{\mu} / \mathbf{m L})$ \\
\hline TB12 & 4.365 \\
20 PM & 8.511 \\
CW17 & 2.979 \\
CW01 & 3.917 \\
11 AC & 3.954 \\
SW14 & 3.062 \\
16 PM & 2.773 \\
\hline
\end{tabular}

$\mathrm{NaIO}_{4}$. Thereby, we could indicate that the responsible compounds in those extracts were polysaccharides. Other than that, we also found that treatment other extract with protease- $\mathrm{K}$ and nuclease resulted in a decrease of antibiofilm activity indicating that the responsible compounds of these extracts are protein and nucleic acid, respectively.

Polysaccharides have been reported to be one of the most common antibiofilm agents. Most of them act as surfactant altering the properties of abiotic and biotic surfaces. In this case, polysaccharides are known to be able to modify the wettability, charge, and hydrophobicity of the surface, hence interfere the interaction between cell-surface. Valle et al. (2006) [19] reported that the treatment of abiotic surfaces with group II capsular polysaccharides led to lowering the interfacial energy and hydrophobicity of the glass surfaces. This caused drastic reduction of initial adhesion and biofilm maturation of wide range of Gram-positive and Gram-negative bacteria. Similarly, Jiang et al. (2011) [18] also reported that exopolysaccharide isolated from marine bacterium Vibrio sp. showed inhibitory activity against cell aggregation of $P$. aeruginosa. In addition, this compound also able to disrupt pre-formed biofilm structure of $P$. aeruginosa. These data suggest that polysaccharides not only could weaken the cell-surface interactions (initial adhesion) but also could interfere cell-to-cell interactions (biofilm maturation). In addition, others modes of action of polysaccharides as antibiofilm agent have been reported, such as down-regulating genes which related to biofilm formation and inducing cellular motility [20].

Protein is also known to be one of antibiofilm agents. Biofilm dispersal is a process which involves destruction of EPS mediated by various matrix-degrading enzymes, such as proteases and deoxyribonuclease (DNAses). The degradation of EPS causes the maturation process on biofilm to be disrupted increasing the sensitivity of the sessile cells to antibiotics and host immune system [21]. Another antibiofilm agent which also found in this study was extracellular DNA (eDNA). This activity was also reported by study conducted by [22], which stated that eDNA secreted by Caulobacter crescentus showed an ability to act as anti-adhesive agent by coating the adhesive surface, thereby inhibiting the initial cell attachment which is required for biofilm formation. In this case, most of these antibiofilm agents work specifically towards particular pathogens in specific mechanism of action.

Brine shrimp lethality assay is a simple, highthroughput cyto-toxicity assay. This assay is based on the killing ability of the compound tested on organismbrine shrimp (Artemia salina). This assay is used as preliminary assay for further toxicity experiment on mammalian animal models. Because it is easy, inexpensive, rapid, give a repetitive result, and accommodates a large number of nauplii for statistical validation. In this assay, we used A. salina as an object for determination of toxicity of compounds tested [23].

In this assay, we determine the value $\mathrm{LC}_{50}$ of each compound tested. $\mathrm{LC}_{50}$ is defined as estimation of the exposure concentration causing $50 \%$ of mortality of A. salina in specified period of time. If the $\mathrm{LC}_{50}$ value of compound tested is more than $1 \mathrm{mg} / \mathrm{mL}$, then the compound is considered non-toxic. Conversely, if the $\mathrm{LC}_{50}$ value of compound tested is less than $1 \mathrm{mg} / \mathrm{mL}$, then the compound is considered toxic [24]. In this study, we found that the $\mathrm{LC}_{50}$ value of all of the extracts tested were more than 1 $\mathrm{mg} / \mathrm{mL}$. Thereby, all of the extracts tested did not have cyto-toxic effect against $A$. salina nauplia. However, these extract needs to be further tested using more advance toxicity assay to ensure their toxicity property.

\section{Conclusion}

In this study, all of the extracts of Actinomycetes isolates, such as 20 PM, CW01, and $11 \mathrm{AC}$ showed potential inhibitory activity towards biofilm structure of all pathogenic bacteria tested. In addition, these extracts also showed antiquorum sensing activity against reporter strain C. violaceum wild-type. We also found through characterization assay that most of the compound contained in these extracts which responsible for their antibiofilm activity were polysaccharides. We also found through characterization assay that most of the compound contained in these extracts which responsible for their antibiofilm activity were polysaccharides. Therefore, we concluded that these extracts are considered to be promising to combat biofilmrelated-infections in aquaculture industry. However, further research about optimization of extract concentration to exhibit better destructive activity towards biofilm structure of all pathogenic tested and more advance toxicity assay are considered necessary to be performed.

\section{Methods}

\section{Bacterial cultivation}

In this study, sixteen Actinomycetes isolates recovered from marine environment, from our previous study and Chromobacterium violaceum WT wild-type were obtained from Atma Jaya Culture Collection. Whereas, Vibrio harveyi and Aeromonas hydrophila were obtained from health aquatic organism laboratory of Department of 
Aquaculture, Faculty of Fisheries and Marine Sciences, Bogor Agricultural Univeristy. Streptococcus agalactiae which were used in this study had been characterized as ATCC 27956.

Cryopreservation isolates of Actinomycetes were streaked onto Tryptic Soya Agar (TSA) (Oxoid) and incubated at $28^{\circ} \mathrm{C}$ for 7 days. Afterwards, single colony was picked, streaked onto yeast malt extract agar $(10 \mathrm{~g}$ Malt extract; $4 \mathrm{~g}$ Yeast extract; $4 \mathrm{~g}$ Glucose; $2 \mathrm{~g} \mathrm{CaCO}_{3} ; 1 \mathrm{~L}$ distilled water) (YMEA), and incubated at $28^{\circ} \mathrm{C}$ for 7 days. Whereas, pathogenic bacteria were streaked onto luria agar $(5 \mathrm{~g} \mathrm{NaCl}$; $5 \mathrm{~g}$ Yeast extract; $10 \mathrm{~g}$ Tripton; $20 \mathrm{~g}$ Agar Bacto; $1 \mathrm{~L}$ distilled water) (LA) and incubated at $28^{\circ} \mathrm{C}$ for overnight.

\section{Primary screening of anti-quorum sensing activity}

This primary screening was performed based on Abudoleh and Mahasneh (2017) [25] method with some modifications. Firstly, Actinomycetes isolates were straight-streak onto LA and incubated at $28^{\circ} \mathrm{C}$ for 3 days. Subsequently, C. violaceum WT wild-type as reporter strain was grown in luria broth (LB) and incubated at $28{ }^{\circ} \mathrm{C}$ for overnight. This culture was diluted in sterile LB until the absorbance value reaches 0.132 at $600 \mathrm{~nm}$ (McFarland 0.5). Then, $100 \mu \mathrm{L}$ of the culture was put into $3 \mathrm{~mL}$ semisolid LA $(0.75 \% \mathrm{w} / \mathrm{v}$ agarbacto). After incubation time of Actinomycetes isolates, the culture was poured onto the LA as an overlay. These plates were incubated at $28^{\circ} \mathrm{C}$ for another 4 days. The result was observed. In this case, positive result was indicated by the inhibition of violacein pigment around the Actinomycetes isolates. Conversely, negative result was indicated by the production of violacein pigment around Actinomycetes isolates.

\section{Fermentation conditions and extracts preparation}

Fermentation and extraction was performed using Balasubramanian et al. (2017) [26] with some modifications. Isolates of Actinomycetes were inoculated into Tryptic soy broth (TSB) $+1 \%$ glucose and incubated at $28^{\circ} \mathrm{C}$ for 7 days at $150 \mathrm{rpm}$ using rotary shaker. Afterwards, the culture was centrigufed at $6900 \mathrm{x}$ g for $15 \mathrm{~min}$. Supernatant was harvested and an equal volume of ethyl acetate was added. The supernatant was incubated at $28^{\circ} \mathrm{C}$ for overnight at $150 \mathrm{rpm}$ using rotary shaker. Then, solvent layer was harvested and evaporated using rotary evaporator to generate extracts. These extracts were dissolved in $1 \%(\mathrm{v} / \mathrm{v})$ dimethyl sulfoxide (DMSO) to generate final concentration $(20 \mathrm{mg} / \mathrm{mL})$. The extracts were used for further assays.

\section{Detection of anti-quorum sensing activity}

This step was performed based on the method published by Rajivgandhi et al. (2018) [27] with some modifications.
Chromobacterium violaceum wild-type was streaked continuously in three directions onto LA using sterile cotton buds. Then, sterile cork borer was used to remove plugs of the agar. This plug was replaced by extract of Actinomycetes isolates. In this assay, DMSO was used as control negative, while Streptomycin $(10 \mathrm{mg} / \mathrm{mL})$ was used as positive control. Plates were incubated at $28^{\circ} \mathrm{C}$ for overnight. Finally, translucent zone against violacein pigmentation of $C$. violaceum wild-type was observed.

\section{Anti-bacterial assay}

Antibacterial assay was performed by using diffusion method according to Bauer et al. (1966) [28] with some modifications. Pathogenic bacteria were inoculated into $\mathrm{LB}$ and incubated at $28^{\circ} \mathrm{C}$ for overnight at $150 \mathrm{rpm}$ using rotary shaker. Afterwards, these cultures were diluted into sterile LB until the absorbance value reaches 0.132 at $600 \mathrm{~nm}$ (McFarland 0.5).

Pathogenic bacteria were streaked in three directions onto Mueller Hinton Agar (MHA) using sterile cotton buds. Afterwards, a sterile cork borer was used to remove the agar plugs. Then, these plugs were replaced by the extract of Actinomycetes isolates. In this assay, DMSO was used as control negative, while Streptomycin $(10 \mathrm{mg} / \mathrm{mL})$ was used as positive control. Plates were incubated at $28^{\circ} \mathrm{C}$ for overnight. Then, clearing zone was observed. The isolate which showed anti-bacterial activity was ruled out in antibiofilm activity assay.

\section{Antibiofilm assay}

Antibiofilm assay was performed in two categories based on their mechanisms, namely inhibitory and destructive activity assay. Preparation of this assay was performed, by inoculating pathogenic bacteria into LB medium. Then, cultures were incubated at $28^{\circ} \mathrm{C}$ for overnight and diluted into sterile LB until the absorbance values reaches 0.132 at $600 \mathrm{~nm}$ (McFarland 0.5).

Antibiofilm assay was performed according to O'Toole and Kolter (1998) [29] with some modifications. For inhibitory activity assay, $200 \mu \mathrm{L}$ of pathogenic bacteria suspension and Actinomycetes isolates extracts was loaded simultaneously into 96 -well polystyrene plates. Then, plates were incubated at $28^{\circ} \mathrm{C}$ for overnight, then staining process was performed. Conversely for destructive activity assay, firstly $200 \mu \mathrm{L}$ of pathogenic bacteria suspension was loaded into 96well polystyrene plates. Plates were incubated at $28^{\circ} \mathrm{C}$ for overnight and Actinomycetes isolates extracts were loaded, then staining process was performed. For both assay, pathogenic bacteria suspensions were used as positive control, while sterile LB was used as negative control.

The process of staining was performed un-aseptically. Planktonic cells and media were discarded. Then, 
adherent biofilm cells were rinsed with water twice and air-dried for $30 \mathrm{~min}$. These cells were stained by using $200 \mu \mathrm{L}$ of $0.4 \%(\mathrm{~b} / \mathrm{v})$ crystal violet for $30 \mathrm{~min}$. Then, crystal violet was discarded. These stained cells were rinsed with water for five times to remove any remaining crystal violet and air-dried for $30 \mathrm{~min}$. Then, $100 \mu \mathrm{L}$ of absolute ethanol was added and re-suspended to dissolve the stained cells. Subsequently, this ethanol was transferred into new 96-well polystyrene plates. The absorbance of each well was measured with microplate reader. Finally, the percentage of antibiofilm activity of Actinomycetes isolates extract was calculated using the formula below [30]:

$$
\% \text { Activity }=\frac{\text { OD Positive control }- \text { OD sample }}{\text { OD positive control }} \times(100 \%)
$$

\section{Determination of the bioactive compounds}

This method was based on this research (Jiang et al. 2011) [18] with some modifications. Some selected extracts of Actinomycetes isolates were treated with proteinase $\mathrm{K}(1 \mathrm{mg} / \mathrm{mL})$, DNase I $(100 \mu \mathrm{g} / \mathrm{mL})$, and $\mathrm{NaIO}_{4}$ $20 \mathrm{mM}$ at $37^{\circ} \mathrm{C}$ for $12 \mathrm{~h}$. Then, the post-treated extracts were used for biofilm inhibition and destruction activity assay. Finally, the activity of pre and post-treated extracts were measured and compared.

\section{Sample preparation for brine shrimp lethality assay (BSLA)} Samples were prepared by dissolving $1 \mathrm{~mL}$ extract of Actinomycetes isolates in $100 \mathrm{~mL}$ artificial sea water in order to get a stock solution $(1000 \mathrm{ppm})$. Then, stock solution was diluted into final concentration $(10,100,500$, and $1000 \mathrm{ppm})$.

\section{Hatching the shrimp}

This method was based on this research (Krishnaraju et al. 2006) [31] with some modifications. Three mg of brine shrimp eggs was added into $\frac{3}{4}$ volume of $1 \mathrm{~L}$ mineral water bottle filled with artificial sea water. Moreover to optimize the hatching process, the growing media was constantly aerated with air pump and illuminated with lamp. After $24 \mathrm{~h}$, the nauplia were collected by pipette and put into tubes.

\section{Bioassay}

Bioassay was performed according to the method published by Ramachandran et al. (2011) [32] with some modifications. Ten nauplia were transferred into tubes filled with $4.5 \mathrm{~mL}$ artificial sea water. Then, $500 \mu \mathrm{L}$ of extracts was added into each tube. Tubes were maintained under illumination for $24 \mathrm{~h}$ at room temperature. Finally, the death percentage of nauplii was determined using this formula below:

$$
\% \text { Death }=\frac{\text { Death nauplii }}{\text { Total nauplii }} \times(100 \%)
$$

In case the negative control does not give $0 \%$ of mortality, the formula was corrected using Abotts's formula below:

$$
\begin{aligned}
\% \text { Death } & =\frac{\text { Death nauplii in tested vial }- \text { death nauplii in control vial }}{\text { Death nauplii in control vial }} \\
& x(100 \%)
\end{aligned}
$$

In this assay, $500 \mu \mathrm{L}$ of $\mathrm{K}_{2} \mathrm{Cr}_{2} \mathrm{O}_{7}$ was be used as positive control, while $500 \mu \mathrm{L}$ of artificial water was used as negative control. The lethal concentration $\left(\mathrm{LC}_{50}\right)$ was collected.

\section{Abbreviations}

EPS: Extracellular polymeric substances; YMEA: Yeast Malt Extract Agar; QSI: Quorum Sensing Inhibitor; AHL: Acylhomoserine lactone; HSL: Homoserine lactone; LA: Luria Agar; LB: Luria Broth; TSB: Tryptic Soy Broth; DMSO: Dimethyl Sulfoxide; MHA: Mueller Hinton Agar; QS: Quorum Sensing; BSLA: Brine Shrimp Lethality Assay

\section{Acknowledgements}

The authors are grateful toward all the supports and would like to thank everyone who contributed in this study. We would like to thank Ministry of Research and Technology of Indonesia which had funded this research. We also thank faculty of fisheries and marine science of Institute of Pertanian Bogor University which had provided several of the pathogenic bacteria cultures.

\section{Limitation}

This study only screened for bioactive compounds which have anti-quorum sensing and antibiofilm activity for several aquaculture pathogenic bacteria, thereby more researches need to be conducted to screen and characterize another compounds which have those activities against another aquaculture pathogenic bacteria. In addition, in this study we only performed preliminary assay of toxicity assay, thereby more advance toxicity assay need to be performed to assure the toxicity property of these extracts.

\section{Authors' contributions}

DEW involved in research design and advisory. GR conducted the research, collected the data, analyzed and processed the data, and prepared the manuscript. DW provided several of pathogen culture and involved in advisory. All authors read and approved the final manuscript.

\section{Funding}

This study was funded by Ministry of Research and Technology of Indonesia (Kementrian Riset dan Teknologi Indonesia). The funder has no contribution in this study.

\section{Availability of data and materials}

All data generated or analysed during this study are included in this published article.

Ethics approval and consent to participate Not applicable.

\section{Consent for publication}

Not applicable. 


\section{Author details}

Master of Biotechnology Program, Faculty of Biotechnology, Atma Jaya Catholic University of Indonesia, Jalan Jenderal Sudirman, Jakarta 12930, Indonesia. ${ }^{2}$ Department of Aquaculture, Faculty of Fisheries and Marine Science, Bogor Agricultural University, Jalan Raya Dramaga, Bogor 16680, Indonesia.

Received: 10 July 2020 Accepted: 27 October 2020

Published online: 12 November 2020

\section{References}

1. FAO. 2020. The state of world fisheries and aquaculture

2. MMAF. Marine affairs and fisheries in figures 2013. Jakarta: MMAF; 2014

3. Flemming HC, Wingender J. The biofilm matrix. Nat Rev Microbiol. 2010;8: 623-33. https://doi.org/10.1038/nrmicro2415.

4. Anderl JN, Franklin MJ, Stewart PS. Role of antibiofilm penetration limitation in Klebsiella pneumoniae biofilm resistance to ampicillin and ciprofloxacin. Antimicrob Agents Chemother. 2000;44:1818-24. https://doi.org/10.1128/ AAC.44.7.1818-1824.2000.

5. $\mathrm{Ma} \mathrm{H}$, Bryers JD. Non-invasive determination of conjugative transfer of plasmids bearing antibiotic-resistance genes in biofilm-bound bacteria: effects of substrate loading and antibiotic selection. Appl Microbiol Biotechnol. 2013;97(1):317-28. https://doi.org/10.1007/s00253-012-4179-9.

6. King RK, Flick GJ, Pierson D, Smith SA, Boardman GD, Coale CW. Identification of bacterial pathogens in biofilms of recirculating aquaculture systems. J Aquat Food Product Technol. 2004;13(1):125-31. https://doi.org/ 10.1300/J030v13n01_11.

7. Gauthier DT. Bacterial zoonoses of fishes: a review and appraisal of evidence for linkages between fish and human infections. Vet J. 2015;203:27-35.

8. Rutherford ST, Bassler BL. Bacterial quorum sensing: its role in virulence and possibilities for its control. Cold Spring Harb Perspect Med. 2012;2:a012427. https://doi.org/10.1101/cshperspect.a012427.

9. Courtois S, Cappellano CM, Ball M. Recombinant environmental libraries provide access to microbial diversity for drug discovery from natural products. Appl Environ Microbiol. 2003;69:49-55. https://doi.org/10.1128/ AEM.69.1.49-55.2003.

10. Pandey B, Ghimire P, Agrawal VP. Studies on the bacterial activity of the Actinomycetes isolated from the Khumbu region of Nepal. Appl Microbiol. 2008;:5:235-61

11. Wijaya M, Delicia D, Waturangi DE. Screening and quantification of antiquorumsensing activity of Actinobacteria isolates against gram-positive and gramnegative biofilm associated bacteria. Durham: Research Square; 2020.

12. Van Bodman SB, Willey JM, Diggle SP. Cell-cell communication in bacteria: united we stand. J Bacteriol. 2008;190:4377-91. https://doi.org/10.1128/JB.00486-08

13. Brackman $G$, Coenye T. Quorum sensing inhibitors as antibiofilm agents. Curr Pharm Des. 2015;21(1):5-11. https://doi.org/10.2174/ 1381612820666140905114627.

14. Rosenthal CB, Mootz JM, Horswill AR. Staphylococcus aureus biofilm formation and inhibition. In: Rumbaugh KP, Ahmad I, editors. Antibiofilm agents: from diagnosis to treatment and prevention. London: Springer; 2015. p. 233-56.

15. Uroz S, Dessaux Y, Oger P. Quorum sensing and quorum quenching: the yin and yang of bacterial communication. Chem Biol Chem. 2009;10:205-16. https://doi.org/10.1002/cbic.200800521.

16. Morohoshi T, Ebata A, Nakazawa S, Kato N, Ikeda T. N-acyl homoserine lactone-producing or-degrading bacteria isolated from intestinal microbial flora of Ayu fish (Plecoglossus altivelis). Microbes Environ. 2005;20(4):264-8.

17. Lynch MJ, Swift S, Kirke DF, Keevil CW, Dodd CER, Williams P. The regulation of biofilm development by quorum sensing in Aeromonas hydrophila. Environ Microbiol. 2002;4(1):18-28.

18. Jiang P, Li J, Han F, Duan G, Lu X, Gu Y, Yu W. Antibiofilm activity of an exopolysaccharide from marine bacterium Vibrio sp. QY101. PLoS One. 2011; 6(4):1-11.

19. Valle J, Re SD, Henry N, Fontaine T, Balestrino D, Lambert PL, Ghigo JM. Broad-spectrum biofilm inhibition by a secreted bacterial polysaccharide. PNAS. 2006;103(33):12558-63. https://doi.org/10.1073/pnas.0605399103.

20. Rendueles O, Kaplan JB, Ghigo JM. Antibiofilm polysaccharides. Environ Microbiol. 2013;15(2):334-46. https://doi.org/10.1111/j.1462-2920.2012.02810.X

21. Roy R, Tiwari M, Donelli G, Tiwari V. Strategies for combathing bacterial biofilms: a focus on antibiofilm agents and their mechanisms of action. Virulence. 2018;9(1):522-54. https://doi.org/10.1080/21505594.2017.1313372.
22. Berne C, Kysela DT, Brun YV. A bacterial extracellular DNA inhibits settling of motile progeny cells within biofilm. Mol Microbiol. 2010;77(4):815-29. https://doi.org/10.1111/j.1365-2958.2010.07267.x.

23. Rajabi S, Ramazani A, Hamidi M, Naji T. Artemia salina as a model organism in toxicity assessment of nanoparticles. DARU J Pharm Sci. 2015;23:20-6.

24. Wu C. An important player in brine shrimp lethality bioassay: the solvent. J Adv Pharm Technol Res. 2014;5(1):57-8.

25. Abudoleh SM, Mahasneh AM. Anti-quorum sensing activity of substances isolated from wild berry associated bacteria. Avicenna J Med Biotechnol. 2017;9(1):23-30

26. Balasubramanian S, Othman EM, Kampik D, Stopper H, Hentschel U, Ziebuhr W, Oelschlaeger TA, Abdelmohsen UR. Marine sponge-derived Streptomyces sp. SBT343 extract inhibits Stpahylococcal biofilm formation. Front Microbiol. 2017;8:236. https://doi.org/10.3389/fmicb.2017.00236.

27. Rajivgandhi G, Vijayan R, Maruthupandy M, Vaseeharan B, Manoharan N. Antibiofilm effect of Nocardiopsis sp. GRG1 (KT235640) compound against biofilm forming gram negative bacteria on UTIs. Microb Pathog. 2018;118: 190-8. https://doi.org/10.1016/j.micpath.2018.03.011.

28. Bauer AW, Kirby WMM, Sherris JC, Turck M. Antibiotic susceptibility testing by a standardized single disk method. Am J Clin Pathol. 1966;45:493-6.

29. OToole GA, Kolter R. Flagellar and twitching motility are necessary for Pseudomonas aeruginosa biofilm development. Mol Microbiol. 1998:30:295-304.

30. Djordjevic D, Wiedmann M, McLandsborough LA. Microtiter plate assay for assessment of Listeria monocytogenes biofilm formation. Appl Environ Microbiol. 2002;68(6):2950-8. https://doi.org/10.1128/aem.68.6.2958.2002.

31. Krishnaraju AV, Rao TVN, Sundararaju D, Vanisree M, Tsay HS, Subbaraju GV. Biological screening of medicinal plants collected from eastern Ghats of India using Artemia salina (brine shrimp test). Int J Appl Sci Eng. 2006;4(2):115-25.

32. Ramachandran S, Vamsikrishna M, Gowthami KV, Heera B, Dhanaraju MD. Assessment of cytotoxic activity of Agave cantula using brine shrimp (Artemia salina) lethality bioassay. Asian J Sci Res. 2011;4(1):90-4. https://doi.org/10.3923/ajsr.2011.90.94.

\section{Publisher's Note}

Springer Nature remains neutral with regard to jurisdictional claims in published maps and institutional affiliations.

Ready to submit your research? Choose BMC and benefit from:

- fast, convenient online submission

- thorough peer review by experienced researchers in your field

- rapid publication on acceptance

- support for research data, including large and complex data types

- gold Open Access which fosters wider collaboration and increased citations

- maximum visibility for your research: over $100 \mathrm{M}$ website views per year

At BMC, research is always in progress.

Learn more biomedcentral.com/submissions 